Ergün, A. ve Temizkan, M. (2022). Ortaokul Türkçe ders kitaplarının sinektik tekniği açısından incelenmesi. Ana Dili Eğitimi Dergisi, 10(1), 157-176.

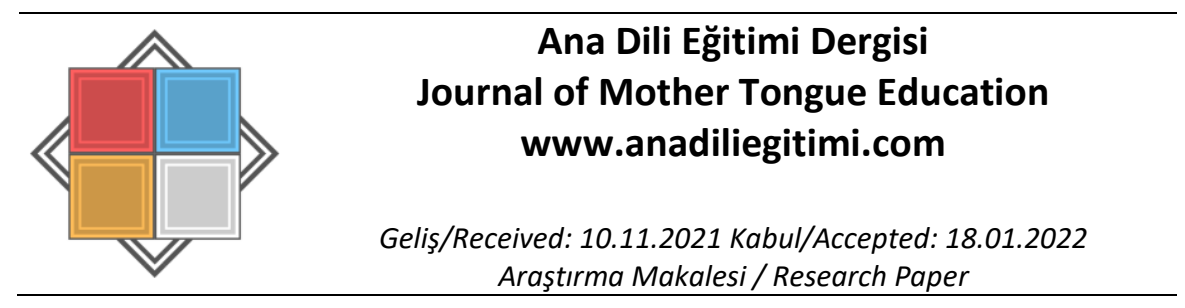

\title{
Ortaokul Türkçe Ders Kitaplarının Sinektik Tekniği Açısından İncelenmesi*
}

\author{
Ayşegül ERGÜN ** \\ Mehmet TEMIZKAN ***
}

\begin{abstract}
Öz
Bu çalışmanın amacı ortaokul düzeyi için hazırlanan (5-8. sınıflar) Türkçe ders kitaplarındaki metinleri yaratııı düşünme tekniklerinden birisi olan sinektik tekniği açısından değerlendirmektir. Araştırmanın veri setini 2005-2006 eğitim öğretim yılından 2018-2019 eğitim öğretim yılına kadar okutulan ortaokul Türkçe ders kitapları oluşturmaktadır. Bu kitaplar içinden araştırmacı tarafından ulaşılabilen toplam 20 ders kitabı veri seti olarak belirlenmiştir. Çalışmada nitel araştırma yöntemlerinden doküman incelemesi; veri toplama aracı olarak "Türkçe Ders Kitaplarına Yönelik Sinektik Uygulamaları Formu" kullanılmışır. Araştırmada ulaşılan verilerin analiz edilmesi amacıyla nitel veri analizi tekniklerinden içerik analizine başvurulmuştur. Yapılan inceleme sonucunda incelenen Türkçe ders kitaplarında toplam 320 sinektik uygulama örneği tespit edilmiştir. Bunlar arasında en fazla \%37,25 orana sahip olan doğrudan analoji örneklerine rastlanmıştır. Bunu fantezi analoji \%21,25; bastııımış çatışma \%17,81; dolaysız analoji \%15,93; kişisel analoji \%7,5 takip etmektedir. Araştırma sonucunda Türkçe ders kitabındaki metinlerin sinektik uygulamalarına göre dengeli bir dağılım göstermediği belirlenmiştir.
\end{abstract}

Anahtar Kelimeler: Ders kitapları, yaratııılık, yaratıcı düşünme, sinektik tekniği

\section{A Review of Secondary School Turkish Course Books in Terms of the Synectic Technique Abstract}

This study aims to evaluate the texts in the secondary school Turkish textbooks in terms of the synectic technique, which is one of the creative thinking techniques. The data consist of the secondary school Turkish textbooks used from 2005 to 2019. A total of 20 textbooks were used for analysis. Document analysis, a qualitative research method, and the "Synectic Applications Form for Turkish Textbooks" were used as the data collection tool in the study. To analyze the data, content analysis, a qualitative data analysis technique, was used. The analysis showed that a total of 320 Synectic application examples were found in the Turkish textbooks. Direct analogy examples had the highest percentage with $37.25 \%$. This was followed by fantasy analogy $/ 21.25 \%$ ), suppressed conflict (17.81\%), and personal analogy (7.5\%). It was determined that the texts in the Turkish textbooks did not show a balanced distribution in terms of synectic applications.

Keywords: Textbooks, creativity, creative thinking, synectic technique

\section{Giriş}

Düşünme insan hayatının en temel etkinliklerinden biri ve onu diğer canlılardan ayıran birincil özelliğidir. Olayları, durumları, kavramları çeşitli boyutlarıyla ele almaya, bunları analiz etmeye,

\footnotetext{
"Bu çalışma "Ortaokul Türkçe ders kitaplarının sinektik tekniği açısından incelenmesi” başlıklı yüksek lisans tezinin bulgularından hareketle üretilmiştir.

** Öğrt., Millî Eğitim Bakanlığı, Türkçe Öğretmeni, Şırnak, E-posta: aysegul.9638@gmail.com, ORCID: orcid.org/0000-0002-9190-8908

${ }^{* * *}$ Prof. Dr., Hatay Mustafa Kemal Üniversitesi, Eğitim Fakültesi, Türkçe ve Sosyal Bilimler Eğitimi Bölümü, Hatay,

E-posta: temizkanm79@gmail.com, ORCID: orcid.org/0000-0001-7437-6754
} 
bunlardan sonuç çıkarmaya dayanan düşünme üst düzey zihinsel işlem basamaklarını içerir. Bu basamakları daha etkili kullanabilmek, düşünme ile yaratıcılığı birleştirmeyi gerektirmektedir. Yaratıcılık genellikle özgünlük, yenilik, sıra dışılık, orijinallik gibi kavramlarla birlikte ele alınır. Yaratıcılık hayal gücü ile ilişkilidir. Yeni bir şey üretme, bir probleme çözüm bulma veya farklı olanla uğraşma manasında kullanılır.

Kökünü, yaratmak ve meydana getirmekten alan yaratıcılık, düşünce gücünden yararlanarak, orijinal bir ürün ortaya koymak ve yaratıcı bir sürece zemin hazırlamaktır. Yaratıcı olma zihinsel üretimin somut bir şekle büründüğü icat veya keşif kavramlarıyla da açıklanabilir. Geçmişten günümüze yaratıcılık kavramı ile ilgili birçok tanım yapılmıştır. Örneğin, J. P. Guilford (1950) Amerikan Psikoloji Derneği'nde yaptığı bir konuşmasında yaratıcılığı; akıcı, esnek, detaylı ve orijinal fikirler üretme olarak tanımlamıştır. Ayrıca beş zihinsel işlem sınıfının yaratıcılıkta önemli rol oynadığını açıklamıştır. Bunlar biliş, bellek, değerleme, yakınsak düşünme ve ıraksak düşünmedir. Yaratıcı Düşünce Testi'ni geliştiren Torrance'a (1969) göre yaratıcılık; problemler, yetersizlikler ve güçlükler karşısında güçlükleri belirleme, tahminler yapma ve eksikliklerle ilgili olarak hipotezler kurma veya hipotezleri değiştirme, çözüm yollarından birini seçme, deneme ve orijinal çözümler ortaya koymaya yönelik sezgisel bir süreçtir. San (1979) yaratıcılık ve sanatsal yaratma ile ilgili zihinsel sürecin yanı sıra duygunluk, duyarlılık ve imgeleme gücünün birlikte var olması gerektiğini ifade ederek çocukların sanatla eğitilmesi gerektiğini önemle vurgular. Rawlinson (1995) ise yaratıcılık ve yaratıcı düşünmeyi daha önce aralarında ilişki kurulmamış nesneler ya da düşünceler arasında ilişki kurulması olarak tanımlamaktadır. Sungur'a göre (1992) yaratıcılık, dünyayı ve çevremizdeki olguları "sorun" olarak tanımlayan görüşe göre yaşamda başarılı olma, sorunlar ve problemlere karşı duyarlı olma; güçlüğü tanımlama, çözüm arama, tahminlerde bulunma ya da eksikliklere ilişkin denenceler üretme, bu denenceleri değiştirme ya da yeniden sınayarak sonucu ortaya koyma sürecidir. Yaratıcılık, olmayan bir şeyi hayal edebilme, bir şeyi herkesten farklı yollarla yapabilme ve yeni fikirler geliştirebilme yeteneğidir (Temizkan, 2011). Yaratıcılık kavramına ilişkin tanımlar incelendiğinde bu kavramın doğasında esnek düşünmenin ve bu düşünme sonunda tek çözüm yolu yerine birçok seçeneğin üretilmesinin yer aldığı görülür. Üretilen düşünce ve çözüm yollarının orijinal ve yeniliğe açık olması da tanımlardan hareketle çıkarılabilecek sonuçlardandır. Yaratıcılıkla ilgili dikkat çeken diğer bir nokta da yaratıcılıkla sanat ilişkisidir. Buna göre yaratıcılık sanatsal tasarımın ve üretimin de temelinde yer almaktadır.

\section{Yaratıcı Düşünme}

Düşünme ve yaratıcılık kavramlarının birleştirilmesiyle elde edilen yaratıcı düşünme, yaratıcılık kavramının beraberinde getirmiş olduğu özellikler üzerine kurulmuş bir düşünme türüdür. Bu düşünme türü yeni imgeler elde etme, bunları birleştirip ayrıştırma, bunu gerece aktarma, gereç üzerinde düşünme, çizgiler, şekiller, renkler arasında niteliksel ilişkiler kurma, uzamsal, anlatımsal ve estetik düzenlemeler bulmaya yöneliktir (Kırışoğlu, 2002). Yaratıcı düşünme yenilik arayan, sorunlara farklı çözüm yolları getirebilen bireylerin düşünme biçimidir. Yaratıcı düşünme, yaratıcılıkla iç içe geçmiş olarak düşüncelerin genellenmesi, düşünme süreçleri, deneyimler ve alınan kararlarla açıklanır. Yukarıdaki tanımlara göre yaratıcı düşünme herhangi bir olay veya durum karşısında farklı fikirler ortaya koymayı, yeni çözümler ve ürünler üretmeyi; günlük hayatta karşılaşılan sorunlara özgün ve çok yönlü çözümler getirmeyi içermektedir. Ayrıca daha önce aralarında bağlantı kurulmamış olay, durum, kavram ve nesneler arasında ilişkiler kurabilme, böylece yeni yaşantılar, yeni deneyimler, özgün düşünceler ve yeni ürünler ortaya koyabilme, herkesin takip ettiği alışılmış yollardan ayrılabilme gibi özellikler de yaratıcı düşünmenin ortak noktalarıdır.

Yaratıcı düşünme, çoğu zaman yaratıcılık ile aynı çerçevede açıklanmıştır. Hatta bu kavramlar zaman zaman birbirinin yerine kullanılmaktadır. Yaratıcılık ve yaratıcı düşünce birebir aynıdır denilemez. Yaratıcılık bir sonuç iken, yaratıcı düşünce ise sadece orijinal bir ürün ortaya koymak değil, bilinen bilgilerden sentezler yapmak, sorunlara farklı çözüm yolları üretmek, yeni durumlara karşı hızlıca uyum sağlayabilmek ve nesnelerin işlevlerini alışılagelmişin dışında kullanabilmektir. Özetle yaratıcı düşünme yaratıcılığa götüren bir süreçtir (Bayındır, 2013). Yaratıcı düşünme zihinsel etkinlikleri kapsamaktadır. Yaratııılık ise yaratıcı düşünme sonucu elde edilen düşünce kalıpları ile özgün ürünler ortaya koyulması ve ürünün pratiğe dökülmesi ile sonuçlanmaktadır (Yurdakal, 2018). 
Yaratıcı düşünmenin kapsamı içerisinde bir fikri, bir ürünü değiştirme, birleştirme, geliştirme, yeni bilgiler ve fikirler üretme, olaylara farklı açıdan yaklaşma ve buluşlar yapabilme gibi eylemlerin yer aldığı söylenebilir. Yaratıcı düşünmenin alt becerileri ise ayrıntılı fikirler geliştirme, sorunlara kendine özgü çözümler bulma, bir fikre farklı açılardan bakma, olaylara bütünsel bakabilme olarak sıralanabilir ve sayılan bu özellikler eğitim yoluyla kazandırılması amaçlanan hedefler arasındadır (Kaplan ve Ercan, 2011).

Yaratıcı düşünme becerisi, hemen her alanda önemli görülmekte ve yaratıcı fikirler gün geçtikçe daha fazla değer kazanmaktadır. Yaratıcılık çoğu zaman doğuştan gelen yeteneklere dayandırılsa da bu beceriyi sezgisel güce ve bilişsel süreçlere dayandırmak mümkündür (Babayiğit, Alagöz Hamzaj ve Çardak, 2018). Yaratıcı düşünme, daha önce aralarında ilişki kurulmayan nesneleri veya görüşleri ilişkilendirmek anlamına gelir ve hayal gücünü üst düzeyde kullanmayı gerektirir (Rawlinson, 1995).

Yaratıcı düşünme, bilinen ana yoldan ayrılıp deneye açık olarak ve kalıpların dışına çıkarak hayal gücünü kullanmayı gerektirir (Özden, 2003). Yaratıcı düşünme olaylar veya durumlar karşısında yeni görüşler öne sürebilmeyi, farklı çözüm yolları ve ürünler üretebilmeyi kapsamaktadır. Bireyin gündelik yaşantıda karşılaştığı problemlere kendine özgü ve çok yönlü çözüm yolları geliştirebilmesidir. Daha önce aralarında bağlantı kurulmamış, ilişkilendirilmemiş nesne, kavram, olay ve durumları ilişkilendirerek farklı ve yeni deneyimler kazanabilme, özgün ürünler ortaya koyabilme yaratıcı düşünmenin ortak özellikleridir (Temizkan, 2011). Bu bağlantıların kurulması ve geliştirilmesi amacıyla zihin sürekli uyanık ve çevreden gelen uyarıcılara karşı açık olmalıdır.

\section{Yaratıcı Düşünme Teknikleri ve Sinektik}

Yaratıcı düşünme tekniklerinin kaynağı, düşünce sahibi olan ve tarihe geçen bilim insanlarının kullandıkları düşünme teknikleridir. Bunlar yaratııı bireyler tarafından farkında olmadan kullanılan, sonrasında bilinç düzeyine çıkarılan ve öğretilebilir teknikler olarak eğitim programlarında yer alan tekniklerdir (Özden, 2005). Altı şapkalı düşünme yöntemi, yanal düşünme tekniği, beyin fırtınası tekniği, nitelik sıralama tekniği ve sinektik tekniği yaratıcı düşünme tekniklerinden birkaçıdır.

Yaratıcı düşünme tekniklerinden birisi olan ve büyük ölçüde Gordon'un (1961) çalışmalarına dayanan sinektik, farklı ve ilgisiz kavramların bir araya getirilmesi anlamına gelmekte ve varsayımları barındırmaktadır.

1. Insanın yaratıcılık gücü doğuştan vardır. Bu yaratıcılık gücü etkinlik gösterdikleri psikolojik süreç içinde farklı zamanlarda belirgin bir şekilde artabilir. Birey kullandığı psikolojik süreçlerin farkında olursa yaratıcı üretkenliği artar.

2. Öğrencilerin yaratıcılık sürecinde çözümlere gerçekçi bir yaklaşımdan daha çok hayalî bir yaklaşım; zihinsel boyuttan daha çok duygusal bir boyutta kurdukları farklı analojiler geliştirmeleri daha önemlidir.

3. Karşılaşılan ve anlaşılması gereken problemlere çözüm bulma sürecinde bu hayal ürünü ve duyusal analoji ögeleri, çözüme ulaşma olasılı̆̆ını artırmaktadır. Yaratıcılığı artırmak için bu boyutları doğru bir biçimde anlamlandırmak ve kullanabilmek gerekmektedir.

Bu hipotezler aslında yaratıcılık potansiyelinin insanda doğuştan var olduğunu kabul etmekle birlikte sonradan belirli süreçler veya tekniklerle geliştirilebildiğini ortaya koymaktadır. Sinektik bu açıdan yukarıda belirtilen hipotezlere uygun olarak tasarlanmıştır; yaratıcılık ve problem çözme kapasitesinin geliştirilmesini desteklemektedir. Problem çözmede sorunu doğru anlamak, problem çözme ve yaratıcı bir sonuç üretmek kadar önemlidir. Çünkü doğru anlaşılamayan probleme yaratıcı bir çözüm üretilse dahi problemi çözüme kavuşturacak bir sonuca ulaşılamayacaktır. Grupla veya bireysel uygulanabilen sinektik tekniği problemlere sistemli bir şekilde yaratıcı çözümler üretebilmeyi sağlar. $\mathrm{Bu}$ tekniğin yaratıcılığa dayanması ve sorun çözme özelliği, eğitimde kullanılması gerektiğinin göstergesidir. Yaratıcılığı kullanarak hayatı kolaylaştıran bu teknik, öğrencilerin yaratıcı fikirler oluşturmasına olanak tanır.

Sinektik, analojileri kullanarak bir konu üzerinde serbestçe fikir üretmeyi gerektiren problem çözme ve yaratıcı düşünme tekniğidir. Analoji kavramının öne çıktığı sinektik tekniğinde yaratıcı düşünme harekete geçirilmektedir. Sinektik ile problem çözme sürecinde analojiler sistematik bir 
biçimde kullanılmaktadır. Gordon sinektik teorisini, yaratıcı sürecin analojik ve mecazi düşünme ile öğretilebileceği inancına dayandırır (Keyes, 2006). Eski bilgiler ile yeni bilgiler arasında kavramsal bir köprü kuran ve kavramlar arasındaki ilişkileri ortaya çıkaran analoji ve metaforlar, sinektik modeline destek niteliği taşımaktadır. Birbiriyle ilişkili veya ilişkisiz kavramlar arasında benzer veya farklı yönlerinden biri ile kurulan bağ, yepyeni bir kavramla bağ kurularak analoji olarak ortaya çıkmaktadır. Sinektik alıştırmaları yaratıcı düşünmeyi teşvik ederek öğrencilerin metafor ve analojileri kullanmalarına olanak tanır. Jones vd. (1994) sinektik uygulamasının üstün yanlarını şu şekilde belirtmişlerdir:

1. Bireylerde ve gruplarda yaratıcılığı arttırır.

2. İşbirlikli öğrenmeyi destekler.

3. Topluluğun birlik ve beraberliğini teşvik eder.

4. Farklı düşünme süreçlerine izin verir.

5. Farklı öğrenme stillerine sahip öğrencilere ulaşır.

6. Hayal gücü ve duyuların kullanılmasına izin verir.

7. Problem çözme ve beyin fırtınası çalışmalarında kullanışlıdır.

8. Kavram kazanımını genişletir.

Sinektik, analoji ve metaforlar yoluyla yaratıcı düşünme ve problem çözme amacıyla kullanılan bir tekniktir. Teknik, öğrencilerin motivasyonel öğrenme ortamları oluşturması için kullanılabilir, çünkü öğrenmesi zor olan karmaşık konulara yeni ve yaratıcı bakış açıları getirir (Nolan ve Williams, 2010; akt, Erişti ve Polat, 2017). Anlaşılamayan konuyu analoji ve metaforlar sayesinde somutlaştııır. Yaratıcı düşünme sayesinde hiç bilinmeyen bir kavram veya konu hakkında yorum yapılabilir.

Sinektik tekniği yaratıcı düşünme becerilerini keşfetmek ve geliştirmek için kullanılmakla birlikte sosyal problemleri çözmede de yardımcıdır (Jones vd. 1994). Sinektik tekniği sosyal problemlerle karşılaşan öğrencilerin yaratıcı düşünmelerini sağlarken okulda ve sosyal hayatta karşılaşacakları sorunlara yaratıcı çözümler üretmelerini de sağlamaktadır. Problem çözme becerisine sahip öğrenci çok yönlü düşünür. Böylece analiz yapma ve birçok fikirden yaratıcı tek bir fikre ulaşmak suretiyle sentez yeteneğini geliştirir.

Sinektik tekniği, öğrenmenin diğer insanlarla işbirliği içinde ve işbirlikli bir şekilde gerçekleşen bir problem çözme süreci olarak kabul edildiği bazı sosyal etkileşim ilkelerini taşımaktadır. Sinektik, bireysel veya gruplar hâlinde çalışılarak, alternatif bakış açılarının kullanımıyla öğrencilerin durumlara farklı bakış açılarıyla yaklaşmalarına yardımcı olabilmektedir (Seligmann, 2007). Grup liderliğini öğretmen yapabilir veya seçilen bir öğrenciye liderlik görevini verebilir. Grup liderinin görevi sinektik yönteminin uygulanması sorumluluğudur. Liderin bu süreçte dikkat etmesi gereken kural kendi kişisel düşüncelerini açıklamamaktır.

Sinektik, işbirlikli öğretim sağlar. Yaratıcılığı bireysellikten kurtarır. Öğrencinin yaratıcı fikirlerinin tahtaya yazılması, diğer öğrencilerin yaratıcı fikirlerini geliştirmesine veya hiçbir fikri olmayan öğrencinin çağrışımlar oluşturmasına yardımcı olur. Ayrıca, eğitimde sinektik kullanımı, farklı öğrenme ve düşünme stilleri olan çeşitli öğrencilere ulaşmayı mümkün kılar. En önemlisi çeşitli bakış açılarının paylaşılması, hoşgörü ve empati ortamı sağlamaktadır. Yazma eğitiminde sinektik uygulamasıyla eğitim ve öğretim anlamında çok çeşitli yaratıcı fikirler elde etmek olasıdır.

\section{Sinektik Tekniği Uygulamaları}

Illgili literatürde sinektik tekniğinin uygulama basamaklarına ilişkin aralarında küçük farklııklar olan bazı sınıflamalar yapılmıştır. Özden'e göre (2005) sinektik mekanizmaları doğrudan analoji, kişisel analoji ve fantezi analojidir. Açıkgöz (2007) sinektik mekanizmalarını kişisel analoji, dolaysız analoji ve bastırımış çatışma olarak sınıflandırmaktadır. Seligmann (2007) ise doğruda analoji, kişisel analoji ve zıtlıkların bir araya gelmesi şeklinde üç sinektik mekanizması belirlemiştir. Sak'a (2020) göre doğrudan analoji, kişisel analoji ve sembolik analoji olmak üzere üç tür sinektik mekanizması bulunmaktadır. Bu sinektik mekanizmalarına ilişkin açıklamalar şu şekildedir:

1. Doğrudan Analoji: Doğrudan analojiler, yakından ilgili görünmeyen kavramlar arasındaki benzetmelerden oluşmaktadır. Yakından ilgili görünmeseler de benzer yönlerinin bulunabileceği işlevler açısından ilişkiler kurularak doğrudan analojiler oluşturulmaktadır. Aralarında çok yakın ilişki 
görünmeyen bir durumu başka bir duruma benzetmek, yaşanılan bir problemi başka bir probleme benzetmek ya da bunlar arasında ilişkiler kurmak doğrudan analoji yapmaktır. Bu analoji türünde bir alandaki nesne ve kavramlar, sahip olunan bilgiler veya üretilecek fikirler diğer alanlarda geliştirilecek olan fikirlerin temelini oluşturur.

2. Kişisel Analoji: Kişinin bir nesne olduğunu hayal etmesi temeline dayanmaktadır. Canlı veya cansız tüm varlıklarla gerçekleştirilebilir. Örneğin; öğrencilerden küresel ısınmadan dolayı evsiz kalan kutup ayılarının yerine kendilerini koyması istenebilir. Bu analoji türü öğrencinin empati duygusunu geliştirmesine yardımcı olur. Özellikle ilkokul çocukları için sıklıkla kullanılan bu analoji türünde çocuklardan kendilerini bir eşyanın yerine koymaları, örneğin ormanda bir ağaç olmaları veya bir saatin yelkovanı olmaları istenerek yaratıcılık güçleri harekete geçirilir.

3. Fantezi Analoji: Bu analoji türünün amacı bir çeşit arzu ve temenniler listesi ortaya çıkarmaktır. Örneğin öğrencilerden insanların yemeden içmeden yaşayabilmesi, istediği yere istediği anda ulaşabilmesi, uçabilmesi vb. arzularını sıralaması istenir. Amaç hayal gücünü güçlendirmek ve kullandırmaktır.

4. Dolaysız Analoji: Basitçe iki nesne ya da kavramın karşılaştırılmasıdır. Karşılaştırma her yönden aynı olmak zorunda değildir. Dolaysız analojinin işlevi gerçek problem koşullarının bir başka duruma aktarılmasıdır. Örneğin, elma kurdunun açtığı tünelle yeraltı tünellerinin karşılaştırılması dolaysız analojiyi oluşturmaktadır.

5. Bastırılmış Çatışma (Zıtlıkların Bir Araya Gelmesi, Sembolik Analoji): Nesnelerin birbirinin karşıtı sözcüklerle bir arada kullanılması ve tanımlanmasıdır. Zıt düşüncelerin veya sözcüklerin bir araya getirilerek kendi içinde çelişkili sözcük grupları veya düşünceler yaratılmasıyla oluşturulur. "Hayat kurtaran tahrip edici", "barış̧̧ı saldırı" ve "güvenli saldııı", "korkunç güzel” tamlamalarında olduğu gibi karşıt durumlar söz konusudur. İlgili literatürde Zıtlıkların Bir Araya Gelmesi veya Sembolik Analoji başlıklarıyla da bilinmektedir. Kavramlar ya da nesneler arasında alışılmışın dışında zıt ilişkiler kurmaya dayanır. Nesnelerin alışıldık işlevine takılmadan, onlara yeni ve farklı işlevler yüklemektir. Sinektik tekniği içerisinde yer alan zıtlıkların bir araya gelmesi yaratıcılık için önemli bir etken olan fikirler arasında alışıımışın dışında çağrışımlar oluşturmayı hedeflemektedir. Örneğin, bir haftada beş gün ve sekiz saat çalışmak yerine, dört gün ve on saat çalışılsaydı ne olurdu? Silgi, yazıları silmek dışında nerede kullanılabilirdi? Bu uygulama sorularında amaç fikirler arasında alışılmışın dışında yeni çağrışımlar kurmaktır.

Illköğretim düzeyinde okutulan tüm derslerde olduğu gibi Türkçe dersleri ile öğrencilerin birçok yönden gelişmesi amaçlanmaktadır. Bunlardan birisi de yaratıcı düşünmedir. Bu bağlamda yürütülen okuma, yazma, dinleme ve konuşma etkinlikleri yoluyla öğrencilerin yaratıcı düşünme becerileri desteklenebilir. Bilindiği gibi Türkçe derslerinde en fazla kullanılan eğitim aracı ders kitaplarıdır. Türkçe ders kitaplarda yer alan metinler yoluyla öğrencilerin hem dil becerileri geliştirilmeye hem de eleştirel düşünme, yaratıcı düşünme, girişimcilik, problem çözme gibi yaşam becerileri desteklenmeye çalışılır. Bu nedenle ders kitaplarına seçilecek metinler öğrencileri düşünme becerileri açısından desteklemeye elverişli olmalıdır. Bu çalışmada Türkçe ders kitaplarındaki metinler yaratıcı düşünmeyi destekleyen sinektik tekniği açısından incelenmiştir.

\section{Problem Cümlesi}

Araştırmanın problem cümlesi "Ortaokul Türkçe ders kitaplarında yer alan metinlerde sinektik uygulamalarının görünümü nasıldır?" şeklindedir.

\section{Alt Problemler} çalışılmıştır:

Araştırmada problem cümlesine bağlı olarak aşağıdaki alt problemlere yanıt bulunmaya

1. Ortaokul Türkçe ders kitaplarında yer alan düz yazı türündeki metinlerde sinektik uygulamalarının görünümü nasıldır?

2. Ortaokul Türkçe ders kitaplarında yer alan şiir türündeki metinlerde sinektik uygulamalarının görünümü nasıldır? 
3. Ortaokul Türkçe ders kitaplarında yer alan düz yazı metinlerindeki sinektik uygulamalarının sınıf düzeylerine göre dağılımları nasıldır?

4. Ortaokul Türkçe ders kitaplarındaki sinektik uygulamaları metinlere göre nasıl bir dağılım göstermektedir?

\section{Yöntem}

Bu bölümde araştırmanın modeli, veri seti, veri toplama aracı, verilerin analizi başlıklarıyla ilgili bilgilere yer verilmiştir.

\section{Araştırmanın Modeli}

Ortaokul Türkçe ders kitaplarındaki metinlerin sinektik tekniği açısından incelenmesini amaçlayan bu çalışmada nitel araştırma yöntemlerinden doküman incelemesi kullanılmıştır. Nitel araştırma "Gözlem, görüşme ve doküman analizi gibi nitel veri toplama tekniklerinin kullanıldığı, algıların ve olayların doğal ortamda gerçekçi ve bütüncül bir biçimde ortaya konmasına yönelik nitel bir sürecin izlendiği araştırma" olarak tanımlanmaktadır (Yıldırım ve Şimşek, 2013: 29). Nitel araştırmalarda yaygın olarak üç veri toplama yöntemi vardır: Görüşme, gözlem ve yazılı dokümanların incelenmesi. Araştırma kapsamında incelenen konuyla ilgili olgu ve olaylar hakkında bilgi içeren yazılı belgelerin analiz edilmesiyle veri sağlanmasına doküman incelemesi denir. Araştırma yapılan alanla ilgili pek çok bilgi, görüşme ve gözlem yapmaya gerek kalmaksızın belge inceleme yoluyla elde edilebilir. Bu sayede araştırmacı zaman ve kaynak tasarrufu sağlamış olur.

Doküman incelemesinde araştırma konusuyla ilgili raporlar, kitaplar, arşiv dosyaları, video ve ses kayıtları, fotoğraflar gibi belgeler özgünlüğü kontrol edilerek sistematik bir şekilde analiz edilir. Bu çalışmada doküman olarak ortaokul Türkçe ders kitapları kullanıımıştır. Çalışma boyunca ders kitaplarındaki okuma metinleri sinektik tekniğinin boyutları olan doğrudan analoji, dolaysız analoji, kişisel analoji, bastırıımış çatışma ve fantezi analoji başlıkları doğrultusunda incelenmiş ve sonuçlar sayısallaştırılarak verilmiştir. Bu yönüyle çalışma doküman incelemesine uygun olarak gerçekleştirilmiştir.

Veri Seti

Araştırmanın veri setini 2005-2006 eğitim öğretim yılından itibaren 2018-2019 eğitim öğretim yılına kadar okutulan ortaokul (5-8. sınıf) Türkçe ders kitapları oluşturmaktadır. Bu kitaplar içinden araştırmacı tarafından ulaşılabilen toplam 20 ders kitabı veri seti olarak belirlenmiştir. Bu kitapların sınıf düzeylerine göre dağılımı aşağıdaki tabloda verilmektedir.

Tablo 1.

Incelenen Kitapların Sınıf Düzeyleri

\begin{tabular}{rcc}
\hline Sınıf Düzeyi & Kitap Sayısı & Toplam \\
5. Sınıf & 3 & \\
6. Sınıf & 7 & 20 \\
7. Sınıf & 7 & \\
8. Sınıf & 3 & \\
\hline
\end{tabular}

Tabloya göre 5 . sınıf düzeyinde $3 ; 6$. sınıf düzeyinde $7 ; 7$. sınıf düzeyinde 7 ve 8 . sınıf düzeyinde 3 ders kitabı veri setinde yer almaktadır. Bu kitapların künye bilgileri aşağıdaki tabloda verilmektedir.

Tablo 2.

Incelenen Kitapların Künye Bilgileri

$\begin{array}{cccc}\mathrm{Nu} & \text { Sınıf Düzeyi } & \text { Yayınevi } & \text { Eğitim-Öğretim Yılı } \\ 1 & \text { 5. Sınıf } & \text { Anıttepe Yayınları } & 2019\end{array}$




\begin{tabular}{cccc}
\hline 2 & 5. Sınıf & Ada Yayınları & 2011 \\
3 & 5. Sınıf & MEB Yayınları & 2018 \\
4 & 6. Sınıf & Koza Yayınları & 2007 \\
5 & 6. Sınıf & MEB Yayınları & 2013 \\
6 & 6. Sınıf & Doku Yayınları & 2009 \\
7 & 6. Sınıf & Eksen Yayınları & 2018 \\
8 & 6. Sınıf & MEB Yayınları & 2018 \\
9 & 6. Sınıf & Ekoyay Yayınları & 2018 \\
10 & 6. Sınıf & MEB Yayınları & 2019 \\
11 & 7. Sınıf & Özgün Yayınları & 2019 \\
12 & 7. Sınıf & Koza Yayınları & 2007 \\
13 & 7. Sınıf & MEB Yayınları & 2013 \\
14 & 7. Sınıf & Pasifik Yayınları & 2013 \\
15 & 7. Sınıf & MEB Yayınları & 2018 \\
16 & 7. Sınıf & MEB Yayınları 2. Kitap & 2018 \\
17 & 7. Sınıf & Ders Destek Yayınları & 2018 \\
18 & 8. Sınıf & MEB Yayınları & 2018 \\
19 & 8. Sınıf & Ada Yayınları & 2011 \\
20 & 8. Sınıf & MEB Yayınları & 2019 \\
\hline
\end{tabular}

\section{Veri Toplama Araçları}

Araştırmada veri toplama aracı olarak "Türkçe Ders Kitaplarına Yönelik Sinektik Uygulamaları Formu" kullanılmıştır. Bu formun geliştirilmesi amacıyla önce yaratıcı düşünme, yaratıcı düşünme kuram ve teknikleri, sinektik tekniği (modeli, uygulamaları) konularında literatür taraması yapılmış ve ilgili kaynaklar incelenmiştir. Bu inceleme sonucunda sinektik uygulamalarının literatürde yaratıcı düşünme tekniklerinden biri olarak ele alındığı tespit edilmiştir. Sonraki aşamada literatür daraltılarak inceleme sinektik uygulamalarıyla ilgili kaynaklara yönlendirilmiştir. Bu kaynaklar arasında konu ile en yakından ve geniş bilgi veren kaynakların Özden (2005), Açıkgöz (2006), Seligmann (2007) ve Sak (2020) şeklinde olduğu tespit edilmiştir. Bu kaynaklarda toplam 12 sinektik mekanizması yer almaktadır. Bunlardan ortak olanlar birleştirildikten sonra geriye 7 sinektik mekanizması kalmaktadır. Bunlar doğrudan analoji, dolaysız analoji, kişisel analoji, fantezi analoji, bastırılmış çatışma, zıtlıkların bir araya gelmesi ve sembolik analojidir. Kaynakların sinektik mekanizmalarının içerikleriyle ilgili verdikleri bilgilere göre bazı mekanizmaların isimlendirmeleri farklı olsa da içeriklerinin benzer oldukları görülmektedir. Buna göre doğrudan analojilerin temeli olaylar, kavramlar, nesneler vb. arasındaki benzetmelere dayanmaktadır. Dolaylı analojide nesne ve kavramlar arasındaki karşılaştırmalar esas alınmaktadır. Kişisel analojide birey kendisini başka bir varlığın yerine koyarak onun gibi düşünmeye, onunla empati kurmaya çalışmaktadır. Fantezi analojide istek, arzu ve taleplerin hayal edilerek ilişkilendirilmesi söz konusudur. Bastırılmış çatışma, zıtlıkların bir araya gelmesi ve sembolik analoji mekanizmalarının içeriğinde ise kavram, olgu ve nesnelerin karşıt sözcüklerle anlatılması, çelişkili gibi görünen ifadelere yer verilmesi durumu bulunmaktadır. Farklı isimlendirilen bu 3 mekanizmanın içeriklerinin ortak olması nedeniyle bunlar tek mekanizma olarak ele alınmış ve böylece dört kaynaktaki sinektik mekanizmalarının sayısı 5 olarak belirlenmiştir. Buna göre ilk 4 mekanizma doğrudan analoji, 
dolaysız analoji, kişisel analoji ve fantezi analojidir. Beşinci mekanizma ise bastırılmış çatışma, zıtıkların bir araya gelmesi ve sembolik analojinin birleştirilmesinden oluşmuştur. Bu 3 mekanizma içerikleri aynı olduğu için araştırmacının tercihiyle "bastırımış çatışma" olarak çalışmaya alınmıştır. Böylece beşinci sinektik mekanizması bastırılmış çatışma olarak tespit edilmiştir. Bu mekanizmalar ve araştırmada esas alınan içerikleri aşă̆ıdaki gibidir:

Doğrudan Analoji: Benzetme yoluyla kurulan bağlantı ve ilişkiler.

Dolaysız Analoji: Karşılaştırma yoluyla kurulan bağlantı ve ilişkiler.

Kişisel Analoji: Empati yoluyla kurulan bağlantı ve ilişkiler.

Bastırılmış Çatışma: Zıtların bir araya gelmesiyle kurulan bağlantı ve ilişkiler.

Fantezi Analoji: Hayal ederek kurulan bağlantı ve ilişkiler.

Sinektik mekanizmalarının belirlenmesinden sonra "Türkçe Ders Kitaplarına Yönelik Sinektik Uygulamaları Formu" aşağıdaki gibi oluşturulmuştur:

Tablo 3.

Türkçe Ders Kitaplarına Yönelik Sinektik Uygulamaları Formu

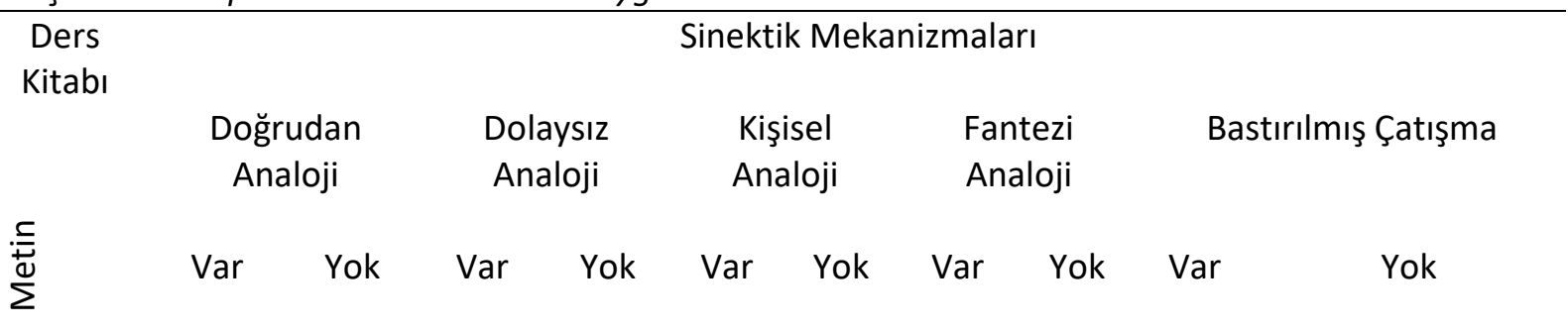

Yukarıda anlatılan işlemlerden sonra Türkçe Ders Kitaplarına Yönelik Sinektik Uygulamaları Formu son şeklini almıştır. Buna göre formda 5 boyut bulunmaktadır. Bu boyutlar formun uygulanma aşamasında "Var / Yok" şeklinde işaretlenmiştir.

\section{Verilerin Analizi}

Türkçe ders kitaplarının sinektik uygulamaları açısından değerlendirildiği bu çalışmada metinler Türkçe Ders Kitaplarına Yönelik Sinektik Uygulamaları Formu kullanılarak analiz edilmiştir. Dolayısıyla çalışmada nitel veri analizi yöntemlerinden betimsel analiz kullanılmıştır. Betimsel analiz, basılı ya da görsel materyallerin sistematik bir şekilde taranarak belli kategoriler bakımından tematik olarak analiz edilmesidir. Yıldırım ve Şimşek (2013)'e göre betimsel analiz önceden belirlenmiş bir çerçeveye bağlı olarak verilerin işlenmesi, bulguların tanımlanması ve tanımlanan bulguların yorumlanması adımlarını içeren analiz yaklaşımıdır. Çalışma kapsamında değerlendirilen metinler önceden belirlenen toplam 5 mekanizma (doğrudan analoji, dolaysız analoji, kişisel analoji, fantezi analoji, bastırılmış çatışma) çerçevesinde analiz edilmiş ve elde edilen veriler sınıflandırılmıştır.

\section{Geçerlik ve Güvenirlik}

Türkçe Ders Kitaplarına Yönelik Sinektik Uygulamaları Formu'nun kapsam geçerliğini sağlamak üzere geniş bir literatür taraması yapılmıştır. Bu tarama sürecinde yaratıcılık, yaratıcı düşünme, yaratıcı düşünme kuramları, yaratıcı düşünme teknikleri, sinektik tekniği kavramlarıyla ilgili birçok kaynak incelenmiştir. Bu inceleme sonucunda özellikle sinektik tekniği ile ilgili en geniş ve ayrıntılı bilgi veren dört kaynak; Özden (2005), Açıkgöz (2006), Seligmann (2007) ve Sak (2020) şeklinde tespit edilmiştir. Bu kaynakların ilgili bölümlerinin analizinden sonra sinektik tekniğinin içeriği ortaya çıkarılmış ve sinektik mekanizmaları en geniş şekliyle ele alınmıştır.

Türkçe Ders Kitaplarına Yönelik Sinektik Uygulamaları Formu'nun güvenilirliğini sağlamak amacıyla form ilk olarak Türkçe ders kitaplarının dışındaki metinlere uygulanmıştır. Bu amaçla çocuk ve genç kuşağa yönelik eserler veren Erol Büyükmeriç, Mavisel Yener, Aytül Akal gibi şair ve yazarların; ayrıca yetişkinlere yönelik olmakla birlikte bu kuşağa yönelik eserleri de olan Nazım Hikmet, Tevfik 
Fikret, Fazıl Hüsnü Dağlarca, Cahit Sıtkı Tarancı, Ali Ulvi Elöve gibi edebiyatçıların metinlerinden seçmeler yapılmıştır. Bu metinler geliştirilen form doğrultusunda analiz edilmiş ve sonraki aşamada araştırmacı ve danışman öğretim üyesi tarafından analiz sonuçları karşılaştırılmıştır. Bu karşılaştırma sonucunda çözümlemeler konusunda fikir birliğine varıldığı görülmüştür. Analiz edilen ve fikir birliğine varılan sinektik mekanizmalarından bazı örnekler aşağıdaki tabloda yer almaktadır.

Tablo 4.

Sinektik Mekanizmaları Örnekleri

\begin{tabular}{cccc}
\hline Doğrudan Analoji & Kişisel Analoji & Bastırılmış Çatışma & Fantezi Analoji \\
$\begin{array}{c}\text { Gece, mısır patlağı dolu } \\
\text { koca bir siyah tas }\end{array}$ & Güneş hasta mı? & $\begin{array}{l}\text { Düşmana amansız ol, } \\
\text { dosta sevecen }\end{array}$ & Yeşilden bir soluk \\
Altın tarlalar & $\begin{array}{c}\text { Göğün mavisini } \\
\text { tattıkça, denizi özlerdi } \\
\text { oyuncak. }\end{array}$ & $\begin{array}{c}\text { Düşüncelerimiz } \\
\text { aydınlatsın karanlıkları }\end{array}$ & $\begin{array}{c}\text { Sattı bana } \\
\text { çocukluğumu }\end{array}$ \\
$\begin{array}{c}\text { Kaf dağları gibi kalın bir } \\
\text { gövde }\end{array}$ & $\begin{array}{c}\text { Gemilerle giden } \\
\text { bulutlar }\end{array}$ & $\begin{array}{c}\text { Koymalıyım güneşi } \\
\text { yüreklerinize }\end{array}$ \\
\hline
\end{tabular}

Tabloda örnekleri verilen sinektik mekanizmaları ve örnekleri üzerinde görüş birliği sağlandıktan sonra çalışmanın veri setini oluşturan kitaplardaki metinler Türkçe Ders Kitaplarına Yönelik Sinektik Uygulamaları Formu doğrultusunda analiz edilmeye başlanmıştır.

\section{Araştırma ve Yayın Etiği}

Bu çalışmada "Yükseköğretim Kurumları Bilimsel Araştırma ve Yayın Etiği Yönergesi" kapsamında uyulması belirtilen tüm kurallara uyulmuştur. Yönergenin ikinci bölümü olan "Bilimsel Araştırma ve Yayın Etiğine Aykırı Eylemler" başlığı altında belirtilen eylemlerden hiçbiri gerçekleştirilmemiştir.

\section{Etik Kurul izni}

Araştırma katılımcılardan veri toplanmasını gerektiren nitel ya da nicel yaklaşımlarla yürütülmediği; deneysel ya da diğer bilimsel amaçlarla insan ya da hayvan kullanılmadığı; klinik çalışma olmadığı; kişisel verileri içermediğinden etik kurul onayı alınmamıştır.

\section{Bulgular}

Bu bölümde araştırma sonucunda elde edilen bulgular alt problemlerin sıralaması gözetilerek verilmektedir.

\section{Birinci Alt Probleme ilişkin Bulgular}

Araştırmanın birinci alt probleminde ders kitaplarındaki şiir metinlerinde bulunan sinektik uygulamalarının tespit edilmesi amaçlanmaktadır. Türkçe ders kitaplarındaki şiir metinlerinde sinektik uygulamalarına ilişkin bulgular aşağıdaki tabloda verilmektedir.

Tablo 5.

Türkçe Ders Kitaplarındaki Şiir Metinlerinde Sinektik Uygulamaları

\begin{tabular}{lcc}
\hline Sinektik Uygulamaları & $\mathrm{f}$ & $\%$ \\
Doğrudan Analoji & 53 & 47,35 \\
Dolaysız analoji & 21 & 18,75 \\
Fantezi Analoji & 15 & 13,39 \\
Bastırılmış Çatışma & 15 & 13,39 \\
\hline
\end{tabular}




\begin{tabular}{lcc}
\hline Kişisel Analoji & 8 & 7,14 \\
Toplam & 112 & 100 \\
\hline
\end{tabular}

Tabloda ders kitaplarında yer alan şiir metinlerindeki sinektik uygulamaları bulunmaktadır. Buna göre şiir metinlerinde toplam 112 sinektik uygulaması kullanılmıştır. Bunlar içinde en sık kullanılan sinektik uygulaması doğrudan analoji $(\% 47,35)$ olmuştur. Onu sırasıyla dolaysız analoji $(\% 18,75)$, fantezi analoji $(\% 13,39)$, bastırılmış çatışma $(\% 13,39)$ izlemektedir. Şiir metinlerinde en az kullanılan sinektik uygulamasının kişisel analoji $(\% 7,14)$ olduğu belirlenmiştir.

\section{İkinci Alt Probleme îlişkin Bulgular}

Araştırmanın ikinci alt probleminde ders kitaplarında bulunan düz yazı metinlerindeki sinektik uygulamalarının tespit edilmesi amaçlanmaktadır. Türkçe ders kitaplarında yer alan düz yazı metinlerindeki sinektik uygulamalarına ilişkin bulgular aşağıdaki tabloda verilmektedir.

Tablo 6.

Türkçe Ders Kitaplarındaki Düz Yazı Metinlerinde Sinektik Uygulamaları

\begin{tabular}{lcc}
\hline Sinektik Uygulamaları & $f$ & $\%$ \\
Doğrudan Analoji & 65 & 31,10 \\
Fantezi Analoji & 47 & 22,48 \\
Bastırılmış Çatışma & 45 & 21,53 \\
Dolaysız analoji & 38 & 18,18 \\
Kişisel Analoji & 14 & 6,69 \\
Toplam & 208 & 100 \\
\hline
\end{tabular}

Tabloda ders kitaplarında yer alan düz yazı metinlerindeki sinektik uygulamaları bulunmaktadır. Buna göre düz yazı metinlerinde en sık kullanılan sinektik uygulaması doğrudan analoji $(\% 31,10)$ olmuştur. Onu sırasıyla fantezi analoji $(\% 22,48)$, bastırılmış çatışma $(\% 21,53)$, dolaysız analoji $(\% 18,18)$ izlemektedir. Düz yazı metinlerinde en az kullanılan sinektik uygulamasının kişisel analoji $(\% 6,69)$ olduğu belirlenmiştir.

\section{Üçüncü Alt Probleme iliş̧kin Bulgular}

Araştırmanın üçüncü alt problemi ders kitaplarında yer alan düz yazı metinlerindeki sinektik uygulamalarının sınıf düzeylerine göre dağılımlarını tespit etmeyi amaçlamaktadır. Sınıf düzeylerine göre düz yazı metinlerindeki sinektik uygulamalarının dağııımları aşağıda verilmektedir.

\section{Beşinci Sınıf Türkçe Ders Kitaplarındaki Düz Yazı Metinlerinde Sinektik Uygulamalarına ilişkin Bulgular}

Beşinci sınıf Türkçe ders kitaplarındaki düz yazı metinlerinde sinektik uygulamalarına ilişkin bulgular aşağıdaki tabloda verilmektedir.

Tablo 7.

Beşinci Sınıf Türkçe Ders Kitaplarındaki Düz Yazı Metinlerindeki Sinektik Uygulamaları

\begin{tabular}{lcccccc}
\hline \multicolumn{1}{c}{ Ders Kitabı } & $\begin{array}{c}\text { Doğrudan } \\
\text { Analoji } \\
\text { (f) }\end{array}$ & $\begin{array}{c}\text { Dolaysız } \\
\text { Analoji } \\
\text { (f) }\end{array}$ & $\begin{array}{c}\text { Kişisel } \\
\text { Analoji } \\
\text { (f) }\end{array}$ & $\begin{array}{c}\text { Bastırılmış } \\
\text { Çatışma } \\
\text { (f) }\end{array}$ & $\begin{array}{c}\text { Fantezi } \\
\text { Analoji } \\
\text { (f) }\end{array}$ & $\begin{array}{c}\text { Toplam } \\
\text { (f) }\end{array}$ \\
Anıttepe 5. Sınıf (2019) & 3 & 1 & 0 & 0 & 0 & 4 \\
MEB 5. Sınıf (2018) & 2 & 3 & 1 & 2 & 3 & 11 \\
Ada 5. Sınıf (2011) & 0 & 0 & 0 & 0 & 3 & 3 \\
Toplam & 5 & 4 & 1 & 2 & 6 & 18 \\
\hline
\end{tabular}


Tabloda beşinci sınıf düzeyindeki ders kitaplarında yer alan düz yazı metinlerindeki sinektik uygulamaları verilmektedir. Buna göre beşinci sınıf Türkçe ders kitaplarında doğrudan analoji $(f=5)$, dolaysız analoji $(f=4)$, kişisel analoji $(f=1)$, bastırılmış çatışma $(f=2)$ ve fantezi analoji $(f=6)$ şeklinde yer almaktadır.

\section{Altıncı Sınıf Türkçe Ders Kitaplarındaki Düz Yazı Metinlerinde Sinektik Uygulamalarına ilişkin Bulgular}

Altıncı sınıf Türkçe ders kitaplarındaki düz yazı metinlerinde sinektik uygulamalarına ilişkin bulgular aşağıdaki tabloda verilmektedir.

Tablo 8.

Altıncı Sınıf Türkçe Ders Kitaplarındaki Düz Yazı Metinlerindeki Sinektik Uygulamaları

\begin{tabular}{lcccccc}
\hline \multicolumn{1}{c}{ Ders Kitabı } & $\begin{array}{c}\text { Doğrudan } \\
\text { Analoji }\end{array}$ & $\begin{array}{c}\text { Dolaysız } \\
\text { Analoji }\end{array}$ & $\begin{array}{c}\text { Kişisel } \\
\text { Analoji } \\
\text { (f) }\end{array}$ & $\begin{array}{c}\text { Bastırılmış } \\
\text { Çatışma } \\
\text { (f) }\end{array}$ & $\begin{array}{c}\text { Fantezi } \\
\text { Analoji }\end{array}$ & $\begin{array}{c}\text { Toplam } \\
\text { (f) }\end{array}$ \\
MEB 6. Sınıf (2019) & 3 & 2 & 1 & 3 & 0 & 9 \\
Eksen 6. Sınıf (2018) & 2 & 1 & 0 & 1 & 0 & 4 \\
MEB 6. Sınıf (2018) & 2 & 1 & 1 & 1 & 2 & 7 \\
Ekoyay 6. Sınıf (2018) & 3 & 0 & 0 & 2 & 3 & 8 \\
MEB 6. Sınıf (2013) & 1 & 2 & 0 & 0 & 2 & 5 \\
Doku 6. Sınıf (2009) & 3 & 0 & 0 & 2 & 1 & 6 \\
Koza 6. Sınıf (2007) & 3 & 2 & 1 & 3 & 9 & 18 \\
Toplam & 17 & 8 & 3 & 12 & 17 & 57 \\
\hline
\end{tabular}

Tabloda altıncı sınıf düzeyindeki ders kitaplarında yer alan düz yazı metinlerindeki sinektik uygulamaları verilmektedir. Buna göre altıncı sınıf Türkçe ders kitaplarında doğrudan analoji $(f=17)$, dolaysız analoji $(f=8)$, kişisel analoji $(f=3)$, bastırılmış çatışma $(f=12)$ ve fantezi analoji $(f=17)$ şeklinde yer almaktadır.

\section{Yedinci Sınıf Türkçe Ders Kitaplarındaki Düz Yazı Metinlerinde Sinektik Uygulamalarına ilişkin Bulgular}

Yedinci sınıf Türkçe ders kitaplarındaki düz yazı metinlerinde sinektik uygulamalarına ilişkin bulgular aşağıdaki tabloda verilmektedir.

Tablo 9.

Yedinci Sınıf Türkçe Ders Kitaplarındaki Düz Yazı Metinlerindeki Sinektik Uygulamaları

\begin{tabular}{|c|c|c|c|c|c|c|}
\hline Ders Kitabı & $\begin{array}{l}\text { Doğruda } \\
\text { n Analoji } \\
\text { (f) }\end{array}$ & $\begin{array}{c}\text { Dolaysı } \\
\text { z } \\
\text { Analoji } \\
\text { (f) }\end{array}$ & $\begin{array}{l}\text { Kişisel } \\
\text { Analoji } \\
\text { (f) }\end{array}$ & $\begin{array}{l}\text { Bastırılm } \\
\text { ış } \\
\text { Çatışma } \\
\text { (f) }\end{array}$ & $\begin{array}{c}\text { Fantezi } \\
\text { Analoji } \\
\text { (f) }\end{array}$ & $\begin{array}{c}\text { Toplam } \\
\text { (f) }\end{array}$ \\
\hline Özgün 7. Sınıf (2019) & 4 & 1 & 1 & 1 & 0 & 7 \\
\hline MEB 7. Sinıf (2018) & 7 & 4 & 1 & 6 & 8 & 26 \\
\hline MEB 7. Sınıf (2018, İkinci Kitap) & 2 & 0 & 0 & 2 & 1 & 5 \\
\hline Ders Destek 7. Sınıf (2018) & 4 & 1 & 0 & 2 & 8 & 15 \\
\hline MEB 7. Sinıf (2013) & 5 & 2 & 0 & 6 & 1 & 14 \\
\hline Pasifik 7. Sınıf (2013) & 4 & 1 & 1 & 0 & 0 & 6 \\
\hline Koza 7. Sinıf (2007) & 2 & 2 & 0 & 1 & 0 & 5 \\
\hline Toplam & 28 & 11 & 3 & 18 & 18 & 78 \\
\hline
\end{tabular}

Tabloda yedinci sınıf düzeyindeki ders kitaplarında yer alan düz yazı metinlerindeki sinektik uygulamaları verilmektedir. Buna göre yedinci sınıf Türkçe ders kitaplarında doğrudan analoji ( $\mathrm{f}=28)$, 
dolaysız analoji $(f=11)$, kişisel analoji $(f=3)$, bastırılmış çatışma $(f=18)$ ve fantezi analoji $(f=18)$ şeklinde yer almaktadır.

\section{Sekizinci Sınıf Türkçe Ders Kitaplarındaki Düz Yazı Metinlerinde Sinektik Uygulamalarına ilişkin Bulgular}

Sekizinci sınıf Türkçe ders kitaplarındaki düz yazı metinlerinde sinektik uygulamalarına ilişkin bulgular aşağıdaki tabloda verilmektedir.

Tablo 10.

Sekizinci Sınıf Türkçe Ders Kitaplarındaki Düz Yazı Metinlerindeki Sinektik Uygulamaları

\begin{tabular}{lcccccc}
\hline \multicolumn{1}{c}{ Ders Kitabı } & $\begin{array}{c}\text { Doğrudan } \\
\text { Analoji } \\
(\mathrm{f})\end{array}$ & $\begin{array}{c}\text { Dolaysız } \\
\text { Analoji }\end{array}$ & $\begin{array}{c}\text { Kişisel } \\
\text { Analoji }\end{array}$ & $\begin{array}{c}\text { Bastırılmış } \\
\text { Çatışma }\end{array}$ & $\begin{array}{c}\text { Fantezi } \\
\text { Analoji }\end{array}$ & Toplam \\
MEB 8. Sınıf (2019) & 11 & 10 & 4 & 12 & 1 & (f) \\
MEB 8. Sınıf (2018) & 2 & 3 & 1 & 1 & 1 & 88 \\
Ada 8. Sınıf (2011) & 2 & 2 & 2 & 0 & 4 & 10 \\
Toplam & 15 & 15 & 7 & 13 & 6 & 56 \\
\hline
\end{tabular}

Tabloda sekizinci sınıf düzeyindeki ders kitaplarında yer alan düz yazı metinlerindeki sinektik uygulamaları verilmektedir. Buna göre sekizinci sınıf Türkçe ders kitaplarında doğrudan analoji $(f=15)$, dolaysız analoji ( $f=15)$, kişisel analoji $(f=7)$, bastırımış çatışma $(f=13)$ ve fantezi analoji $(f=6)$ şeklinde yer almaktadır.

\section{Sinektik Uygulamalarının Tüm Sınıf Düzeylerindeki Düz Yazı Metinlerine Göre Dağılımlarına ilişsin Bulgular}

Sinektik uygulamalarının tüm sınıf düzeylerindeki düz yazı metinlere göre dağılımlarına ilişkin bulgular aşağıdaki tabloda verilmektedir.

Tablo 11.

Sinektik Uygulamalarının Tüm Sınıf Düzeylerine Göre Dağılımları

\begin{tabular}{|c|c|c|c|c|c|c|}
\hline Ders Kitabı & $\begin{array}{l}\text { Doğrudan } \\
\text { Analoji } \\
\text { (f) }\end{array}$ & $\begin{array}{l}\text { Dolaysız } \\
\text { Analoji } \\
\text { (f) }\end{array}$ & $\begin{array}{l}\text { Kişisel } \\
\text { Analoji } \\
\text { (f) }\end{array}$ & $\begin{array}{l}\text { Bastırılmış } \\
\text { Çatışma } \\
\text { (f) }\end{array}$ & $\begin{array}{l}\text { Fantezi } \\
\text { Analoji } \\
\text { (f) }\end{array}$ & $\begin{array}{c}\text { Toplam } \\
\text { (f) }\end{array}$ \\
\hline 5. Sinif & 5 & 4 & 1 & 2 & 6 & 18 \\
\hline 6. Sinıf & 17 & 8 & 3 & 12 & 17 & 57 \\
\hline 7. Sinif & 28 & 11 & 3 & 18 & 18 & 78 \\
\hline 8. Sinıf & 15 & 15 & 7 & 13 & 6 & 56 \\
\hline Toplam & 65 & 38 & 14 & 45 & 47 & 208 \\
\hline
\end{tabular}

Tabloda tüm sınıf düzeylerine göre düz yazı metinlerindeki sinektik uygulamaları verilmektedir. Buna göre düz yazı metinlerinde toplam 208 sinektik uygulaması kullanılmıştır. En fazla sinektik uygulaması 7. sınıf ( $f=78$ ) olmuştur. 6. sınıf düzeyinde ( $f=57)$, 8. sınıf düzeyinde $(f=56)$ ve 5 . sınıf düzeyinde $(\mathrm{f}=18)$ sinektik uygulaması kullanılmıştır.

\section{Dördüncü Alt Probleme ilişskin Bulgular}

Araştırmanın dördüncü alt problemi sinektik uygulamalarının ders kitaplarında yer alan metin türlerine göre dağılımlarını tespit etmeyi amaçlamaktadır. Dördüncü al probleme ilişkin bulgular aşağıdaki tabloda verilmektedir. 
Tablo 12.

Sinektik Uygulamalarının Ders Kitaplarındaki Metin Türlerine Göre Dağılımı

\begin{tabular}{lcccccccccccc}
\hline Türler & \multicolumn{2}{c}{ Doğrudan } & \multicolumn{2}{c}{ Dolaysız } & \multicolumn{2}{c}{ Kişisel } & \multicolumn{2}{c}{ Bastırılmış } & \multicolumn{2}{c}{ Fantezi } & \multicolumn{2}{c}{ Toplam } \\
& \multicolumn{2}{c}{ Analoji } & \multicolumn{2}{c}{ Analoji } & \multicolumn{2}{c}{ Analoji } & \multicolumn{2}{c}{ Çatışma } & \multicolumn{2}{c}{ Analoji } & & \\
& $\mathrm{f}$ & $\%$ & $\mathrm{f}$ & $\%$ & $\mathrm{f}$ & $\%$ & $\mathrm{f}$ & $\%$ & $\mathrm{f}$ & $\%$ & $\mathrm{f}$ & $\%$ \\
Şiir & 57 & 47,5 & 20 & 39,21 & 9 & 37,50 & 16 & 17,24 & 20 & 29,41 & 122 & 100 \\
Hikâye & 21 & 17,5 & 11 & 21,56 & 7 & 29,56 & 21 & 36,84 & 27 & 39,70 & 87 & 100 \\
Deneme & 20 & 20 & 8 & 15,60 & 4 & 16,66 & 6 & 10,52 & 13 & 19,11 & 51 & 100 \\
Roman & 10 & 8,33 & 5 & 9,80 & 3 & 12,50 & 1 & 1,72 & 1 & 1,47 & 20 & 100 \\
Sohbet & 2 & 1,66 & 2 & 3,92 & 1 & 4,16 & 5 & 8,77 & 1 & 1,47 & 11 & 100 \\
Makale & 3 & 2,50 & 3 & 5,88 & - & 0 & 3 & 5,26 & 1 & 1,47 & 10 & 100 \\
Efsane & 2 & 1,66 & 1 & 1,96 & - & 0 & 1 & 1,75 & 3 & 4,41 & 7 & 100 \\
Anı & 2 & 1,66 & - & 0 & - & 0 & 1 & 1,75 & - & 0 & 3 & 100 \\
Destan & 1 & 0,83 & - & 0 & - & 0 & 1 & 1,75 & - & 0 & 2 & 100 \\
Tiyatro & - & 0 & - & 0 & - & 0 & 1 & 1,75 & 1 & 1,47 & 2 & 100 \\
Gezi yazısı & 1 & 0,83 & - & 0 & - & 0 & - & 0 & - & 0 & 1 & 100 \\
Biyografi & 1 & 0,83 & - & 0 & - & 0 & - & 0 & - & 0 & 1 & 100 \\
Masal & - & 0 & 1 & 1,96 & - & 0 & - & 0 & - & 0 & 1 & 100 \\
Mektup & - & 0 & - & 0 & - & 0 & 1 & 1,75 & - & 0 & 1 & 100 \\
Otobiyografi & - & 0 & - & 0 & - & 0 & 1 & 1,75 & - & 0 & 1 & 100 \\
Toplam & 120 & 100 & 51 & 100 & 24 & 100 & 57 & 100 & 68 & 100 & 320 & 100 \\
\hline
\end{tabular}

Tabloda sinektik uygulamalarının Türkçe ders kitaplarındaki metin türlerine göre dağılımları yer almaktadır. Buna göre en fazla sinektik uygulaması şiir türündeki metinlerde $(f=122)$ kullanılmıştır. Bunu hikâye ( $f=87$ ) ve deneme ( $f=51)$ türündeki metinler izlemektedir. Sinektik uygulamalarının roman $(f=20)$, sohbet $(f=11)$ ve makale $(f=10)$ türündeki metinlerde de kullanıldığı görülmektedir. Geriye kalan efsane ( $f=7)$, anı $(f=3)$, destan $(f=2)$, tiyatro $(f=2)$, gezi yazısı $(f=1)$, biyografi $(f=1)$, masal $(f=1)$, mektup $(f=1)$, otobiyografi $(f=1)$ türlerinde sinektik uygulamalarının kullanımı sınırlı kalmıştır. Metin türlerine göre sinektik uygulamalarının dağılımına bakıldığında en fazla doğrudan analojinin kullanıldı̆ı belirlenmiştir. Doğrudan analoji şiir türünde $(f=57)$, hikâye türünde $(f=21)$ ve deneme türünde $(f=20)$ sıklığında kullanılmıştır.

\section{Tartışma ve Sonuç}

Araştırma sürecinde veri setini oluşturan ders kitaplarının değerlendirilmesi sonucunda şiir türündeki metinlerdeki toplam sinektik uygulamaları 112 olarak tespit edilmiştir. Bunların sinektik mekanizmalarına göre dağılımları ise doğrudan analoji $(f=53)$, dolaysız analoji $(f=21)$, bastırımış çatışma ( $f=15)$, fantezi analoji $(f=15)$ ve kişisel analoji $(f=8)$ şeklindedir. Buna göre veri setini oluşturan Türkçe ders kitaplarında yer alan şiir türündeki metinlerde en fazla rastlanan sinektik mekanizması $\% 47,35$ oranıyla doğrudan analoji olmuştur. Bunu sırasıyla \%18,75 ile dolaysız analoji, \%13,39 ile bastırılmış çatışma, \%13,39 ile fantezi analoji ve \%7,14 ile kişisel analoji takip etmektedir.

Veri setini oluşturan ders kitaplarının değerlendirilmesi sonucunda düz yazı türlerindeki toplam sinektik uygulamaları 208 olarak tespit edilmiştir. Bunların sinektik mekanizmalarına göre dağılımları ise doğrudan analoji $(f=65)$, fantezi analoji $(f=47)$, bastırılmış çatışma ( $f=45)$, dolaysız analoji $(f=38)$ ve kişisel analoji $(\mathrm{f}=14)$ şeklindedir. Buna göre veri setini oluşturan Türkçe ders kitaplarındaki metinlerde en fazla rastlanan sinektik mekanizması \%31,10 oranıyla doğrudan analoji olarak belirlenmiştir. Bunu $\% 22,48$ ile fantezi analoji, \%21,53 ile bastırılmış çatışma, \%18,18 ile dolaysız analoji ve \%6,69 ile kişisel analoji takip etmektedir.

Araştırma sürecinde veri setini oluşturan ders kitaplarının değerlendirilmesi sonucunda düz yazı ve şiir türündeki metinlerde toplam 320 sinektik uygulaması belirlenmiştir. Bunların sinektik mekanizmalarına göre dağııımı doğrudan analoji $(f=120)$, fantezi analoji $(f=68)$, bastırılmış çatışma $(f=57)$, dolaysız analoji $(f=51)$ ve kişisel analoji $(f=24)$ şeklinde gerçekleşmiştir. Buna göre araştırma 
sürecinde değerlendirilen Türkçe ders kitaplarındaki doğrudan analoji \%37,25, fantezi analoji \%21,25, bastırılmış çatışma \%17,81, dolaysız analoji \%15,93 ve kişisel analoji \%7,5 oranıyla yer almaktadır.

Araştırmada elde edilen başka bir sonuç da sinektik uygulamalarının ders kitaplarındaki metin türlerine göre dağııımlarına ilişkindir. Buna göre en fazla sinektik uygulaması şiir türündeki metinlerde $(f=122)$ kullanılmıştır. Bunu hikâye $(f=87)$ ve deneme $(f=51)$ türündeki metinler izlemektedir. Sinektik uygulamalarının roman $(f=20)$, sohbet $(f=11)$ ve makale $(f=10)$ türündeki metinlerde de kullanıldığı görülmektedir. Geriye kalan efsane $(f=7)$, anı $(f=3)$, destan $(f=2)$, tiyatro $(f=2)$, gezi yazısı $(f=1)$, biyografi $(f=1)$, masal $(f=1)$, mektup $(f=1)$, otobiyografi $(f=1)$ türlerinde sinektik uygulamalarının kullanımı sınırlı kalmıştır. Türkçe ders kitaplarında sinektik uygulamalarının metin türlerine göre dağılımlarına bakıldığında en fazla sinektik uygulamasının şiir türündeki metinlerde kullanıldığı görülmektedir. Şiir türündeki metinler doğrudan analoji, dolaysız analoji ve kişisel analoji uygulamalarında birinci sırada yer almaktadır. Bastırımış çatışma ve fantezi analoji türlerinde ise hikâye metinleri birinci sırayı almaktadır. Deneme ve roman türlerindeki metinlerde tüm sinektik mekanizmalarıın kullanıldığı görülmektedir. Makale, anı, sohbet, efsane, gezi yazısı, biyografi, destan, masal, tiyatro, mektup ve otobiyografi türlerindeki metinlerde sinektik uygulamalarının sayıca az olduğu tespit edilmiştir.

Sinektik uygulamalarının her biri kendi içinde değerlendirildiğinde şöyle bir durum ortaya çıkmaktadır. Türkçe ders kitaplarındaki metinlerde toplam 120 doğrudan analoji uygulamasına rastlanmıştır. Bunların \%47,50'si şiir, \%17,50'si hikâye, \%20'si deneme, \%8,33'ü roman, \%2,50'si makale türünde bulunmaktadır. İncelenen ders kitaplarında toplam 51 dolaysız analoji tespit edilmiştir. Bunların \%39,21'i şiir, \%21,56'sı hikâye, \%15,60'ı deneme, \%9,80'i roman, \%5,88'i makale türünde bulunmaktadır. Araştırmanın veri setini oluşturan ders kitaplarında toplam 24 kişisel analoji örneğine rastlanmıştır. Bunların \%37,50'si şiir, \%29,56'sı hikâye, \%16,66'sı deneme, \%12,50'si roman, \%4,16'sı sohbet türünde bulunmaktadır. İncelenen ders kitaplarında toplam 57 bastırılmış çatışma örneğine rastlanmıştır. Bunların \%17,24'ü şiir, \%36,84'ü hikâye, \%10,52'si deneme, \%1,75'i roman, \%5,26'sı makale, $\% 8,77$ 'si sohbet türünde bulunmaktadır. Incelenen ders kitaplarında toplam 68 fantezi analoji örneğine rastlanmıştır. Bunların \%29,41'i şiir, \%39,70'i hikâye, \%19,11'i deneme, \%4,41'i efsane türündeki metinlerde bulunmaktadır.

Türkçe ders kitaplarında sinektik uygulamalarının metin türlerine göre dağılımlarına bakıldığında en fazla sinektik uygulamasının şiir türündeki metinlerde kullanıldığı görülmektedir. Şiir türündeki metinler doğrudan analoji, dolaysız analoji ve kişisel analoji uygulamalarında birinci sırada yer almaktadır. Bastırılmış çatışma ve fantezi analoji türlerinde ise hikâye metinleri birinci sırayı almaktadır. Deneme ve roman türlerindeki metinlerde tüm sinektik mekanizmalarıın kullanıldığı görülmektedir. Makale, anı, sohbet, efsane, gezi yazısı, biyografi, destan, masal, tiyatro, mektup ve otobiyografi türlerindeki metinlerde sinektik uygulamalarının sayıca az olduğu tespit edilmiştir.

Araştırmadan elde edilen sonuçlara göre doğrudan analoji, dolaysız analoji ve kişisel analoji uygulamaları en fazla şiir türündeki metinlerde görülmektedir. Şiir büyük ölçüde yaratıcılığa dayanan, imge ve imajların üzerine temellendirilen, sanatlı anlatımın yoğun olarak işlendiği bir edebî türdür. Şairler duygularını, coşkularını en az kelimeyle en etkili bir şekilde anlatmak durumunda oldukları için şiir hem içerik hem de dil anlamında yoğun bir üründür. Bu özelliklerinden dolayı şiir türündeki metinlerde sinektik uygulamalarının yoğun olması beklenen bir durumdur. Edebî sanatlardan benzetmeye dayalı doğrudan analoji, kavramlar ve nesneler arasındaki karşılaştırmaya dayanan dolaysız analoji, yaratıcılı̆ın ve empati duygusunun desteklendiği kişisel analoji uygulamalarının en fazla şiir türündeki metinlerde kullanılması, bu türün içerik ve dil özellikleriyle de uyumlu bir durumdur.

Araştırmaya konu olan sinektik mekanizmalarından bastırılmış çatışmalara en fazla hikâye türündeki metinlerde rastlanmaktadır. Bastırılmış çatışmalar zıt ifade, kavram, görüntü vb. bir araya getirilmesine dayanmaktadır. Hikâye türündeki metinlerde kişi, yer ve nesne betimlemelerine çokça yer verilmesi ve bu betimlemelerin okuyucu üzerindeki etkisinin artırılması amacıyla zıt ifadelerden yararlanılmaktadır. Bu durum hikâye türündeki metinlerde sinektik uygulamalarından bastırılmış çatışmanın sıklık düzeyini artırmaktadır.

Sinektik türlerinden yaratıcılık ve hayal gücüne dayanan fantezi analoji uygulamaları en fazla hikâye türündeki metinlerde kullanılmıştır. Değerlendirilen ders kitaplarındaki hikâye metinlerinin bir kısmının bilim ve teknoloji temasına ait olduğu düşünüldüğünde fantezi analojinin bu türdeki 
metinlerde sıklıkla kullanılmasının nedeni anlaşılmaktadır. Geleceğe dönük gerçekleşmesi hayal edilen durumların ağılıkta olduğu fantezi analoji, incelenen metinlerde yaratıcılığı ve farklı olanı doğrudan barındıran ifadeler bağlamında kullanılmaktadır.

Sinektik ile ilgili yapılan çalışmalarda şu sonuçlara ulaşılmıştır. Balkır’a (2016) göre sinektik modelin, yabancı dil yazma derslerinde bir yazma öncesi tekniği olarak kullanılabileceği sonucuna varılmıştır. Elde edilen bulgular ile İngilizce yazma sürecinde sinektik tekniğinin öğrencilerin yaratıcı düşünsel düzeylerinin program sonunda anlamlı bir şekilde yükseldiğini gözlemlemiştir. Ercan (2010) sinektik tekniğinin fen bilimleri dersinde kullanılması sonucunda öğrencilerin çalıştıkları kavramlara ait başlangıçta göremedikleri özellikleri görür duruma geldiklerini, nesnelere yüzeysel bakmak yerine çalıştıkları nesneleri derinlemesine bir bakış açısıyla inceler hâle geldiklerini tespit etmiştir. Ayrıca öğrencilerin problem durumlarına getirdikleri farklı ve yaratıcı çözüm önerileri sayısında artış gösterdiklerini savunmaktadır.

Yaratıcı yazma ile ilgili yapılan çalışmalarda ise Saygılı (2008) analojilerle ilgili yaptığı deneysel çalışmada analoji temelli yöntemin yaratıcı düşünme üzerinde orta düzeyde ve olumlu bir etkisi olduğunu tespit etmiştir. Yaratıcı düşünme tekniklerinin yaratıcılığı arttırdığını savunan diğer araştırmacılar ise Candar (2009) ve Kuyubaşıoğlu (2009)'dur. Candar, kendisinin hazırladığı yaratıcı düşünme tekniklerini yapılandırmacı eğitimle bütünleştirerek öğrencilere uygulamıştır. Kuyubaşığlu ise yaratıcı düşünme tekniklerinden en fazla beyin fırtınası ve yaratıcı dramanın öğrencilerin yaratıcılıklarını arttırdığını belirtmiştir. Özcan (2009) yaratıcı düşünme etkinliklerinin öğrencilerin yaratıcı düşünmelerine ve proje geliştirmelerine etkisini araştırmıştır ve yaratıcı düşünme etkinliklerinin proje geliştirme çalışmalarına olumlu etkisi olduğunu tespit etmiştir. Yapılan incelemeler sonucunda benzer sonuçları elde eden diğer bir araştırma Ceran Aydın (2010)'ın yaptığı araştırmadır. Araştırmacı fen ve teknoloji dersinde yaratıcı düşünme teknikleri ile geliştirilen etkinliklerin öğrenci başarısına ve tutumuna olumlu yönde etkisi olduğu sonucuna ulaşmıştır. Çelik (2015) öğrencilerin yaratıcı düşünme etkinliklerinin kullanımının, öğrencilerin derse yönelik başarı düzeyleri ve derse karşı tutumları üzerinde olumlu etkisi olduğunu söylemiştir.

Özdemir Erem (2015) çalışmasında yaratıcı düşünme etkinliklerinin görsel okuma ve görsel sunu becerilerine etkisini araştırmıştır. Yaratıcı düşünme etkinliklerinin görsel okuma üzerinde etkisi olmadığını ancak yaratıcı düşünme teknikleri ile yürütülen derslerin görsel tasarımın kalıcılığına katkı sağladığını açıklamıştır. Ayrıca öğrenciler, yaratıcı düşünme teknikleri ile yürütülen dersleri eğlenceli bulmakta ve bu tekniklerle oluşturulmuş etkinliklerin Türkçe dersini sevdirdiğini ifade etmektedirler. Yurdakal (2018) yaratıcı okuma çalışmalarının yaratıcı düşünme becerisine etkisini araştırmıştır. Araştırma sonucunda yaratıcı okuma uygulamalarının öğrencilerin okuma başarılarını, okumaya yönelik tutumlarını, yaratıcı düşünme becerilerini ve yaratıcı okumaya yönelik algılarını olumlu yönde etkilediği tespit edilmiştir.

Yaratıcı düşünme etkinliklerinin ilköğretim öğrencilerinin yaratıcı web sitesi geliştirmelerine etkisini inceleyen Saç (2011) bu araştırmaya zıt olarak bilişim teknolojileri dersinde deney ve kontrol grubunu yaratıcı web site geliştirmeleri bakımından öz yeterlik ve yaratıcılık açısından incelemiştir. Yaratıcı düşünme etkinlikleri ile karşılaşan deney grubu öğrencileri ile bu etkinliklerle karşılaşmayan kontrol grubu öğrencileri arasında yaratıcılık açısından anlamlı bir fark tespit etmemiştir. Sadece deney grubunun öz yeterliliğinde bir artış tespit etmiştir.

Yaratıcı yazma ile ilgili yapılan çalışmalarda Saygıı (2008); Palandökenlier (2008); Candar (2009); Kuyubaşığlu (2009); Özcan (2009); Ceran Aydın (2010); Çelik (2015); Duyar (2019); Aydın (2020) araştırmamız doğrultusunda yaratıcı düşünme teknik ve etkinliklerinin yaratıcılık üzerinde olumlu etkisini tespit etmişlerdir. Aksine Saç (2011) ise araştırmasında yaratıcı düşünme etkinliklerinin yaratıcılık açısından anlamlı bir fark yaratmadığını belirtmektedir.

Yaratıcı düşünmeyi etkileyen faktörler üzerinde çalışan araştırmacılar olmuştur. Dilek (2013) sosyokültürel özelliklerin yaratıcı düşünme üzerinde etkisini araştırmıştır. Bu araştırmada cinsiyet, okul öncesi eğitim, not ortalaması, sınıf, ortalama aylık gelir, internet kullanımı ve okunan kitap sayısı değişkenleriyle yaratıcılık düzeyleri arasında anlamlı bir farka rastlanmamıştır. Annenin ve babanın öğrenim durumu, annenin ve babanın meslekleri değişkenleriyle yaratıcılık düzeyleri arasında anlamlı farka rastlanılmıştır. Yaratıcı düşünme becerisinin okul başarısı, cinsiyet gibi belirgin değişkenlerden 
bağımsız olması bu düşünme becerisinin okul desteği ve her türlü sosyal iletişim aracıyla gelişebileceğini göstereceği savunulmuştur. Toyran (2015) çeşitli değişkenler açısından okul öncesi öğretmen adaylarının yaratıcı düşünme düzeylerini ve eleştirel düşünme eğilimlerini araştırmıştır. Araştırmasındaki değişkenler şunlardır: cinsiyet, anne ve babanın eğitim düzeyi, okudukları sınıf, mezun oldukları lise türüdür. Araştırmanın sonucunda yaratıcı düşünme düzeylerinin cinsiyet, anne baba eğitim durumu ve mezun oldukları lise türüne göre anlamlı bir fark bulunamamıştır. Öğrencilerin eleştirel düşünme eğilimleri ile anne baba eğitim durumları ve mezun oldukları lise türüne göre anlamlı bir farklılık bulunmazken cinsiyete ve öğrenim gördükleri sınıfa göre ise analitik düşünme boyutunda anlamlı bir farka rastlanmıştır. Yaratıcılık puanları ile eleştirel düşünme eğilimleri arasındaki ilişki karşılaştırıldığında Öztürk Çağlayan (2013) aksine düşük düzeyde de olsa pozitif yönde bir fark bulunmuştur. Adıgüzel (2016) ise yaratıcılığı etkileyen etmenleri sınıf çerçevesinde sınırlandırarak yaratıcılık üzerinde öğretmenin etkisini incelemiştir. Sınıf öğretmenlerinin yaratıcılık düzeylerine ilişsin görüşleri arasında cinsiyet, mesleki kıdem ve mezuniyet durumu değişkenleri açısından anlamlı bir farklııı bulunmamıştır. Sınıf öğretmenlerinin görüşlerine göre yaratıcı düşünme becerileri ile davranışlarının öğrencilerin yaratıcı düşünme becerilerinin gelişimine katkısı arasında pozitif yönde ve orta düzeyde anlamlı bir ilişki bulunduğu tespit edilmiştir.

Durnacı (2019) araştırmasında yaratıcı düşünme ve eleştirel düşünme ilişkisine değinirken bu düşünme becerilerini etkileyen etkenler üzerinde ayrıca durmuştur. Araştırmasına konu edindiği araştırmanın sonucunda sınıf öğretmeni adaylarının yaratıcı düşünme eğilimlerinin ortanın üzerinde olduğu ve sınıf, cinsiyet, aile gelir düzeyi ve ebeveyn eğitim düzeyi değişkenlerinin yaratıcı düşünme eğilimi üzerinde anlamlı bir etkisinin olmadığı tespit edilmiştir. Midilli (2019) ise yaratıcılığı etkileyen faktörlere özel yetenekli öğrencilere etkisi açısından yaklaşmaktadır. Araştırma sonunda elde ettiği bulgulara göre öğrencilerin özel yeteneklilik alanları, okul öncesi eğitim alma durumu, sınıf ve yaş düzeyleri arasında anlamlı fark bulunurken cinsiyet, anne baba eğitim düzeyi, aile gelir durumu, kardeş sayısı, doğum sırası, okul türü ve anne baba yaşı arasında anlamlı bir fark bulunmadığı tespit edilmiştir. Bu sonuçlar doğrultusunda yaratıcılık üzerinde yaratıcı düşünme tekniklerinin etkisinin incelenebileceği düşünülebilir. Yaratıcılığı etkileyen çok çeşitli etmenler arasında okul bulunmaktadır. Öğrencinin öğretim esnasında en çok karşılaştığı materyal ise ders kitaplarıdır. Bunun yanı sıra öğretmen ve öğretmenin kullandığı öğretim yöntem ve tekniklerin önemi yadsınmamalıdır. Bu doğrultuda öğrencinin sınıfta karşılaştığı durum ve olasılıklar değerlendirilebilmeli yaratıcılık açısından ölçülmesi gerektiği kabul edilmelidir.

Duyar (2019) öğrencilerin yaratıcı düşünme becerilerini öğretmen görüşlerine göre değerlendirmiştir. Öğretmenler ise yaratıcı öğrencilerin davranışları arasında ilk özelliğin "özgünlük" olduğu görüşünü belirtmişlerdir. Okulda yaratıcı düşünmeyi geliştirmek için yeterli ders saatlerinin olmadığı, okul ortamını yetersiz gördükleri ve ders kitaplarındaki metinleri yaratıcılık açısından yetersiz buldukları sonucuna ulaşımıştır. Öğretmenlerin öğrencilerin yaratıcı düşünme becerisinin gelişmesinde kullanılan yönteme ilişkin görüşlerinde ise canlandırma ve dramanın; tekniğe ilişkin görüşlerinde ise beyin fırtınasının ön plana çıktığı sonucuna ulaşımıştır. Yaratıcı düşünmenin yaratıcı yazmaya etkisi üzerinde duran Aydın (2020) çalışmasında yaratıcı yazma üzerinde yaratıcı düşünmenin etkisini çalışmamıza ait yöntemle belirlemeyi amaçlamıştır. Araştırmasında Türkçe ders kitaplarını incelemiştir. Araştırmanın sonucunda yaratıcı düşünme becerisinin yaratıcı yazma yöntemini destekler nitelikte olduğunu; yaratıcı düşünme becerisinin, yaratıcı yazma yönteminin kullanıldığı etkinliklerin tamamında yer aldığını fakat ders kitaplarında yeterli yaratıcı yazma etkinliklerine yer verilmediği belirtmiştir. Bu araştırma sonucu araştırmamızı destekler niteliktedir. Yaratıcılık üzerine yapılan çalışmalar değerlendirildiğinde çoğunluk itibariyle elde edilen veri ve sonuçlarla, çalışmamızın sonucunda ulaştığımız "yaratıcılığı arttırmak için yaratıcı düşünme tekniklerinden yararlanıımalı" hipotezi benzerlik teşkil etmektedir.

\section{Araştırma ve Yayın Etiği}

Bu çalışmada "Yükseköğretim Kurumları Bilimsel Araştırma ve Yayın Etiği Yönergesi" kapsamında uyulması belirtilen tüm kurallara uyulmuştur. Yönergenin ikinci bölümü olan "Bilimsel 
Araştırma ve Yayın Etiğine Aykırı Eylemler" başlığı altında belirtilen eylemlerden hiçbiri gerçekleştirilmemiştir.

\section{Etik Kurul izni}

Araştırma katılımcılardan veri toplanmasını gerektiren nitel ya da nicel yaklaşımlarla yürütülmediği; deneysel ya da diğer bilimsel amaçlarla insan ya da hayvan kullanılmadığı; klinik çalışma olmadığı; kişisel verileri içermediğinden etik kurul onayı alınmamıştır.

\section{Yazarların Katkı Oranı}

Çalışmaya birinci yazar \%60, ikinci yazar \%40 oranında katkı sağlamıştır.

\section{Kaynaklar}

Açıkgöz, K. Ü. (2007). Aktif öğrenme. İzmir: Biliş Yayıncılık.

Adıgüzel, Ö. (2006). Yaratııı drama kavramı; bileşenleri ve aşamaları. Yaratıcı Drama Dergisi, 1(1), 1730.

Aiamy, M. ve Haghani, F. (2012). The effect of synectics and brainstorming on 3rd grade students' development of creative thinking on science. Procedia-Social and Behavioral Sciences, 47, 610613.

Asmalı, M. ve Dilbaz Sayın, S. S. (2016). The effects of the Synectics Model on vocabulary learning, attitude and desire to learn English. Asian EFL Journal, 18(3), 41-60.

Aydın, B. (2020). Yaratıcı düşünmenin yaratıcı yazmaya etkisi (Yayımlanmamış yüksek lisans tezi). Gazi Üniversitesi Eğitim Bilimleri Enstitüsü, Ankara.

Babayiğit, B., Alagöz Hamzaj, Y. ve Çardak, Ç. S. (2018). Yaratıcı düşünmeyi destekleyici bir bağlantıcı öğrenme etkinliği: Analoji duvarı. Ilköğretim Online, 17(4). DOI:10.17051/ilkonline.2019.506953.

Balkır, N. (2016). Sinektik modelinin yükseköğrenim düzeyindeki olası İngilizce becerilerine etkisi (Yayımlanmamış doktora tezi). Çanakkale Onsekiz Mart Üniversitesi Eğitim Bilimleri Enstitüsü, Çanakkale.

Bayındır, N. (2013). Çocuklarda yaratıcılık ve geliştirilmesi. Ankara: Eğiten Kitap.

Candar, H. (2009). Fen eğitiminde yaratıcı düşünme öğretim tekniklerinin öğrencilerin akademik başarı, tutum ve motivasyonlarına etkisi (Yayımlanmamış yüksek lisans tezi). Marmara Üniversitesi Eğitim Bilimleri Enstitüsü, İstanbul.

Ceran Aydın, S. (2010). Yaratıcı düşünme teknikleri ile geliştirilen fen etkinliklerinin öğrenci başarısı ve tutumuna etkisi (Yayımlanmamış yüksek lisans tezi). Selçuk Üniversitesi Eğitim Bilimleri Enstitüsü, Konya.

Çelik, E. A. (2015). 7. sınıf sosyal bilgiler dersinde yaratıcı düşünme etkinliklerinin kullanımı (Yayımlanmamış yüksek lisans tezi). Adnan Menderes Üniversitesi Sosyal Bilimler Enstitüsü, Aydın.

Dilek, A. N. (2013). Sosyo-kültürel özelliklerin yaratıcı düşünmeye etkisi (Yayımlanmamış yüksek lisans tezi). Eskişehir Osmangazi Üniversitesi Eğitim Bilimleri Enstitüsü, Eskişehir.

Djudin, T. (2017). Synectics model: An offer to develop students' creativity through science learning. Eğitim, Öğretme ve Öğrenme Dergisi, 2, 65-70. DOI:10.26737/jetl.v2i1.608.

Durnacı, Ü. (2019). Sınıf öğretmeni adaylarının eleştirel ve yaratıcı düşünme eğilimlerinin belirlenmesi ve karşılaştırılması (Yayımlanmamış yüksek lisans tezi). Giresun Üniversitesi Sosyal Bilimler Enstitüsü, Giresun.

Duyar, M. (2019). Türk dili ve edebiyatı öğretmenlerinin yaratıcı düşünme becerilerine ilişkin görüşleri (Yayımlanmamış yüksek lisans tezi). Sivas Cumhuriyet Üniversitesi Eğitim Bilimleri Enstitüsü, Sivas.

Ercan, S. (2010). Fen öğretiminde yaratıcı düşünme tekniklerinden sinektik kullanımına yönelik bir eylem araştırması (Yayımlanmamış Yüksek lisans tezi). Sakarya Üniversitesi, Eğitim Bilimleri Enstitüsü, Sakarya. 
Erişti, B. ve Polat, M. (2017). The effectiveness of synectics instructional model on foreign language vocabulary teaching. Online Submission, 5(2), 59-76. DOI:10.18298/ijlet.1753.

Guilford, J. P. (1967). Creativity: Yesterday, today, and tomorrow. The Journal of Creative Behavior, 1(1), 3-14.

Hızır, B. (2014). Ilköğretimde yaratıcı okumanın yaratıcı düşünme becerisine etkisi (Yayımlanmamış yüksek lisans tezi). Muğla Sıtkı Koçman Üniversitesi Eğitim Bilimleri Enstitüsü, Muğla.

Jones ve diğerleri (1994). Synectics (Brainstorming). Based on excerpts from the expert educator (Unpublished doctoral thesis). University of Nothern Colorado, Colorado.

Kaplan, A. Ö. ve Ercan, S. (2011). Yaratıcı düşünme tekniklerinden sinektik uygulamasına örnek bir araştırma: Çocuğun gözünde yaratıcılık. Uluslararası Insan Bilimleri Dergisi, 8(2), 765-793.

Keyes, K, D. (2006). Metaphorical voices: Secondary students' exploration into multidimensional perspectives in literature and creative writing using the synectics model. Houston: University of Houston Publication.

Kırışoğlu, O. T. (2002). Sanatta eğitim: Görmek, öğrenmek, yaratmak. Ankara: Pegem A Yayınları.

Kuyubaşıoğlu, B. (2009). Illköğretim sosyal bilgiler dersinde yaratıcı düşünme becerilerinin kazandırılması ile ilgili öğretmen ve öğrenci görüşleri (Yayımlanmamış yüksek lisans tezi). Mersin Üniversitesi Sosyal Bilimler Enstitüsü, Mersin.

Loy C. J. (2011). Synectics and creative writing. Minnesota: University of Winona.

Midilli, M. (2019). Özel yetenekli ilkokul öğrencilerinin yaratıcı düşünme becerilerinin bazı değişkenlere göre incelenmesi (Yayımlanmamış yüksek lisans tezi). Ordu Üniversitesi Sosyal Bilimler Enstitüsü, Ordu.

Özcan, S. (2009). Yaratıcı düşünme etkinliklerinin ögrrencilerin yaratıcı düşünmelerine ve proje geliştirmelerine etkisi (Yayımlanmamış yüksek lisans tezi). Gazi Üniversitesi Eğitim Bilimleri Enstitüsü, Ankara.

Özdemir Erem, N. H. (2015). Yaratıcı düşünme tekniklerinin 5. sınıf öğrencilerinin görsel okuma ve görsel sunu becerilerine etkileri (Yayımlanmamış doktora tezi). Atatürk Üniversitesi Eğitim Bilimleri Enstitüsü, Erzurum.

Özden, Y. (2005). Öğrenme ve ögrretme. Ankara: Pegem Yayıncılık.

Öztürk Çağlayan, Ç. (2013). Illköğretim sekizinci sınıf öğrencilerinin bilimsel süreç, eleştirel düşünme ve yaratıcı düşünme becerileri arasındaki ilişkinin incelenmesi (Yayımlanmamış doktora tezi). Gazi Üniversitesi Eğitim Bilimleri Enstitüsü, Ankara.

Palandökenlier, i. (2008). Illköğretim sosyal bilgiler dersi çalışma kitaplarında yer alan etkinliklerin yaratıcı düşünme becerisi açısından değerlendirilmesi (Yayımlanmamış yüksek lisans tezi). Çukurova Üniversitesi Sosyal Bilimler Enstitüsü, Adana.

Ramadhani, S., Ansari, K. ve Hadi, W. (2017). The effect of synectics learning model and vocabulary mastering to students writing poetry skill in grade V. Journal of Research and Method in Education, 75, 80-88. DOI: 10.9790/7388-0705038088.

Rawlinson, G. (1995). Yaratıcı düşünme ve beyin fırtınası (O. Değinilen, Çev.). İstanbul: Rota Yayınları.

Saç, N. (2011). Yaratıcı düşünme etkinliklerinin ilköğretim öğrencilerinin yaratıcı web sitesi geliştirmelerine etkisi (Yayımlanmamış yüksek lisans tezi). Sakarya Üniversitesi Eğitim Bilimleri Enstitüsü, Sakarya.

Sak, U. (2020). Yaratıcılık geliş̧imi ve eğitimi. Ankara: Vize Yayıncılık.

San, i. (1979). Sanatsal yaratma ve çocukta yaratıcılık. Ankara: Tisa Matbaası.

Saygılı, S. (2008). Analoji ile öğretim yönteminin 9. sınıf öğrencilerinin matematik başarılarına ve yaratıcı düşünmelerine etkisi (Yayımlanmamış yüksek lisans tezi). Çanakkale Onsekiz Mart Üniversitesi Sosyal Bilimler Enstitüsü, Çanakkale.

Seligmann, E. R. (2007) Reaching students through synectics: A creative solution (Unpublished doctoral thesis). University of Northern Colorado, Colorado.

Sungur, N. (1992). Yaratıcı düşünce. İstanbul: Özgür Yayın Dağıtım.

Temizkan, M. (2011). Türkçe öğretiminde yaratıcı düşünmeyi geliştirme bakımından Nasreddin Hoca fıkraları. Mustafa Kemal Üniversitesi Sosyal Bilimler Enstitüsü Dergisi, 8(16), 195-223. 
Torrance, E. P., ve Aliotti, N. C. (1969). Sex differences in levels of performance and test-retest reliability on the Torrance tests of creative thinking ability. The Journal of Creative Behavior, 3(1), 52-57.

Toyran, G. (2015). Okul öncesi öğretmen adaylarının yaratıcı düşünme düzeylerinin ve eleştirel düşünme eğilimlerinin bazı değişkenler açısından incelenmesi (Yayımlanmamış yüksek lisans tezi). Dokuz Eylül Üniversitesi Eğitim Bilimleri Enstitüsü, İzmir.

Yasavur, H. (2013). Ilköğretim 3. sınıf hayat bilgisi dersinde öğrencilere yaratıcı düşünme becerisini kazandırmak için önerilen etkinliklerin öğretmenler tarafından kullanılma sıklıkları (Malatya ili örneği) (Yayımlanmamış yüksek lisans tezi). İnönü Üniversitesi Eğitim Bilimleri Enstitüsü, Malatya.

Yıldııı, A. ve Şimşek, H. (2013). Sosyal bilimlerde nitel araştırma yöntemi. Ankara: Seçkin Yayınları.

Yurdakal, i. H. (2018). Yaratıcı okuma çalışmalarının 4. sınıfta okuma ve yaratıcı düşünme becerilerini geliştirmeye etkisi (Yayımlanmamış yüksek lisans tezi). Pamukkale Üniversitesi Eğitim Bilimleri Enstitüsü, Denizli.

\section{Introduction}

\section{Extended Abstract}

Thinking is one of the most basic activities of human life, and it is the primary feature that distinguishes human beings from other living things. Creativity is considered with concepts such as originality, novelty, unusualness, and originality. It is associated with imagination, and it is used to produce something new, find a solution to a problem, or deal with something different. Creative thinking is a type of thinking based on the concept of creativity. There are various techniques to develop creative thinking. The synectic technique is one of them. It is a technique that requires generating ideas freely on a subject through synectic analogies. Creative thinking is activated by the synectic technique, in which the concept of analogy stands out. Analogies are used systematically in the problem-solving process. Analogies and metaphors establish a conceptual bridge between old information and new information, reveal the relationships between concepts, and support the synectic model. The bond established between related or unrelated concepts emerges as an analogy and establishes a connection with a brand-new concept. Synectic exercises encourage creative thinking and allow students to use metaphors and analogies. Turkish courses aim to develop students in many ways, including their creative thinking. The creative thinking skills of students can be supported through reading, writing, listening, and speaking activities carried out in the course. Through the texts, both the language skills of students are developed, and their basic life skills are supported. For this reason, the texts to be selected for textbooks should develop the students' thinking skills. In this study, the texts found in Turkish textbooks were examined in terms of the synectic technique.

\section{Method}

In this study, document analysis, a qualitative research method, was used. The data consisted of the secondary school taught from 2005 until 2019. The "Synectic Applications Form for Turkish Textbooks" was used as the data collection tool. To develop this form, a literature review on creative thinking, creative thinking theories and techniques, the synectic technique (model, applications), and related sources were examined. The review showed that there was a total of 12 synectic mechanisms in the literature. The common ones were combined, and the final number of synectic mechanisms was 5. The texts were analyzed according to those 5 synectic mechanisms included in the form. Descriptive analysis, a qualitative data analysis method, was used in the study.

\section{Results and Discussion}

The total number of synectic applications in the poetry texts was 112 . The identified synectic mechanisms were direct analogy $(f=53)$, direct analogy $(f=21)$, suppressed conflict $(f=15)$, fantasy analogy $(f=15)$, and personal analogy $(f=8)$. Thus, the most common synectic mechanism in poetry texts was direct analogy (47.35\%). This was followed by suppressed conflict (13.39\%), fantasy analogy (13.39\%), and personal analogy (7.14\%). 
The total number of synectic applications in the prose texts was 208 . The identified synectic mechanisms were direct analogy $(f=65)$, fantasy analogy $(f=47)$, suppressed conflict $(f=45)$, and personal analogy $(\mathrm{f}=14)$. Thus, the most common synectic mechanism in the prose texts was direct analogy (31.10\%). This was followed by fantasy analogy (22.48\%), suppressed conflict $(21.53 \%)$, and personal analogy (6.69\%).

A total of 320 synectic applications were found in the poetry and prose texts. The distributions of the synectic mechanisms were direct analogy $(f=120)$, fantasy analogy $(f=68)$, suppressed conflict $(f=57)$, and personal analogy $(f=24)$. The percentages were direct analogy $(37.25 \%)$, fantasy analogy (21.25\%), suppressed conflict (17.81\%), and personal analogy $(7.5 \%)$.

In terms of the distribution of synectic applications according to the text types, they were used mostly in poetry texts $(f=122)$. This was followed by story $(f=87)$ and essay $(f=51)$ texts. Synectic applications were also used in novel $(f=20)$, conversation $(f=11)$ and article $(f=10)$ texts. The distribution of synectic applications in the remaining texts was limited: legend $(f=7)$, memoir $(f=3)$, epic $(f=2)$, theater $(f=2)$, travel writing $(f=1)$, biography $(f=1)$, fairy tale $(f=1)$, letter $(f=1)$, and autobiography $(f=1)$.

In conclusion, synectic applications were mostly used in poetry texts. Direct analogy and personal analogy applications led the others. In terms of suppressed conflict and fantasy analogy applications, story texts took the first place. All synectic mechanisms were also used in essay and novel texts. The number of synectic applications in the article, memoir, conversation, legend, travel writing, biography, fairy tale, play, letter, and autobiography texts was low. 